УДК 304.4:316.7:32

DOI: $10.32837 / 2519-8858 / 10 / 131$

Ганна Миколаївна Сащук

д-р політ. наук, профессор, професор Інституту журналістики

Київський національний університет імені Тараса Шевченка, м. Київ, Україна

\title{
ВІРТУАЛІЗАЦІЯ РЕАЛЬНОСТІ ЯК ФЕНОМЕН КУЛЬТУРИ СУЧАСНОГО ІНФОРМАЦЙНОГО СУСПІЛЬСТВА
}

\begin{abstract}
Анотація. Визначено, що віртуальна реальність - це новий організований соціальний простір, який на противагу відображення реальної дійсності є джерелом відмінності, заміщення, маніпуляцій, симулякрів - особливих об'єктів «відчужених знаків». 3'ясовано, що важливою характеристикою віртуальної культури $є$ іï мозаїчність, пов'язана 3 особливостями процесу пізнання, а також структурування та ціннісного відбору соціального досвіду життєдіяльності. Як наслідок інтенсивного впровадження комп'ютерних інформаційних технологій у повсякденну культуру, безперервного і безладного потоку інформації, формується певний тип віртуальної культури, що поєднує в собі випадкові елементи культур різних народів та епох. Продемонстровано як дані елементи осідають за певними статистичними законами у свідомості індивідів, утворюючи щось на зразок «сховища повідомлень». Досліджено, що визначальною рисою віртуальної культури $є$ побудований за принципом мультимедійного гіпертексту віртуальний простір, тобто специфічна організація інформаційних масивів, елементи яких пов'язані між собою асоціативними відносинами. Зазначено, що через специфіку просторової організації віртуальної реальності, у віртуальній культурі формується інша логіка мислення: нелінійна, непослідовна, недетерміністская, асоціативна. Ці ефекти досягаються завдяки моделюванню «іншого соціуму» та «іншого часу», відмінного від реального соціального часу неодновимірного, оборотного, різноспрямованого і нескінченного. Підсумовується, що завдячуючи віртуальній реальності, не відбувається ціннісного відбору і структурування соціального досвіду, як у випадку спрямованого процесу пізнання, що реалізується за допомогою системи освіти. У цьому полягає основна відмінність віртуальної культури від культури в іiі традиційному розумінні в науці як ціннісно-відібраного та символіко-семіотично організованого досвіду багатьох людей.
\end{abstract}

Ключові слова: віртуальна реальність, віртуальна культура, віртуальний простір, ціннісний вибір, соціальний досвід, маніпулювання, симулякри.

Постановка проблеми. Вступ людства у III тисячоліття позначений процесами, які істотним чином трансформували сучасну соціокультурну реальність. Розвиток засобів масової комунікації і повномасштабне впровадження нових інформаційних технологій призвели до того, що взаємодія людей в сучасному суспільстві все більше набуває віртуального характеру. У результаті інтенсивної інформатизації та глобалізації соціальних і культурних процесів стала можливою поява нового соціального простору - віртуальної реальності. Проблематика віртуальної реальності давно вийшла за межі наукової сфери кібернетики і досягла кордонів гуманітарного знання, де має свій вияв у рамках соціальнофілософської, психологічної та культурологічної проблематики. Спектр досліджень феномену віртуальної реальності в цих сферах охоплює цілу низку проблем, однією з яких $\epsilon$ формування нової віртуальної культури, яка, безперечно, має специфічні риси.

Віртуальна реальність має різні прояви: у формі образів літератури, театру, а віднедавна - радіо й телебачення. Проте сучасне визначення віртуальної реальності дійшло до нас за допомогою комп'ютера.

Десь до кінця 70-х років минулого сторіччя поняття «віртуальність» не асоціювалося ані 3 електронними, ані 3 інформаційними технологіями: воно скромно залишалося синонімом «можливого», допоки в мовному вжитку не почало з'являтися ефектне словосполучення - «віртуальна реальність». Так стали називати тривимірні макромоделі «великої» реальності, які створювалися за допомогою комп'ютера й давали ефект повної присутності в цих псевдореальностях людини. Існує безліч невирішених питань, наприклад, що відбувається 3 «нормальним розумом», коли ми входимо у віртуальну 
реальність, і чому деколи не можемо визначити, де справді реальний світ. Використання систем віртуальної реальності викликало чимало проблем, таких, як відчуження індивіда, маніпулювання свідомістю та ін.

Мета статті - проаналізувати феномен віртуальної реальності в контексті формування культури сучасного інформаційного суспільства.

Виклад основного матеріалу. «Новітній філософський словник» визначає віртуальну реальність категорією постнекласичної науки: це «сукупність об'єктів наступного (щодо реальності, що їх презентує) рівня» [1, с. 171-172]. У цьому контексті віртуальна реальність розглядається як концептуалізація революційного рівня розвитку техніки і технологій, що створює нові виміри культури та суспільства.

Вітчизняний дослідник феномену інформаційного суспільства Я. Любивий принагідно зазначає: «...найсучасніші тенденції розвитку суспільства демонструють, що одним 3 найеврістичніших напрямів досліджень інформаційного та інформаційносинергетичного суспільства $\epsilon$ той, що поєднується 3 аналізом віртуальних вимірів соціальних процесів» [2, с.284]. В соціально-політичній думці (В. Данил'ян, О. Дзьобань, О. Дубас, А. Срмоленко, В. Лях, В. Лук'янець, В. Пазенок, Д. Свириденко, М. Хилько та ін.) вже давно зафіксоване і теоретично обгрунтоване існування зв'язку між феноменом віртуальної реальності та концептом інформаційного суспільства. Поряд із цим існує необхідність у чіткішому визначенні специфіки такого зв'язку, у його концептуальному осмисленні в контексті формування культури інформаційного суспільства.

Так, дослідник С. Хоружий робить спробу методологічної розробки мови опису віртуальної реальності в межах діяльнісного дискурсу зазначає: «Віртуальна реальність не $\epsilon$ автономним родом буття, онтологічним горизонтом. Вона $\epsilon$ своєрідним суб-горизонтом, являючи собою не рід, недорід буття» [3, с. 66]. Таке сприйняття віртуальної реальності зумовлює негативну оцінку С. Хоружим «віртуалістичного світосприйняття», що властиве сучасній людині, коли існує тенденція до сприйняття реальності як багатовимірної, сценарної, варіативної, у якій «все більше місце належить модельній і ігровій, рухливій, пластичній і проблематичній стихії» [3, с. 67].

Феномен віртуальної реальності як побічний продукт сучасного розвитку технологій негативно витлумачується дослідником, як такий, що призводить до деградації людини: «Ми вже наближаємося до виникнення «віртуалістичного світосприйняття» та людини, орієнтованої на віртуальність - орієнтованої на усіх рівнях своєї організації, починаючи 3 тілесної. У сфері комп'ютерних технологій і мас-культури, культури року та кліпу, моментально-дискретних естетичних блоків, що спалахують та змінюються, перцептивний апарат людини весь перебудовується та настроюється на віртуальність, входить в особливий віртуальний режим. До того ж, глибина та масштаб цієї перцептивної та іншої трансформації психосоматики - тим більше, іiі наслідки - швидше за все, проявили себе ще далеко не повною мірою» [3, с. 67].

До негативістських, на нашу думку, належить теорія віртуальної реальності, розроблена М. Кунафіним та Р. Ярцевим. Вони аналізують онтологічні питання, центральним $з$ яких є розробка онтології віртуального буття. Однією з провідних ідей, яку обстоюють дослідники, є визнання існування «особливої форми реальності - мовної реальності або, за бажанням, мовного буття» [4, с. 131], яке ототожнюється з віртуальною реальністю. Одним з основних онтологічних вимірів феномену віртуальної реальності, на їхню думку, є iї ірреальність: «Характеризуючи віртуальну реальність як ірреальну, я розумію, що вона може бути будь-якою в межах мовних значень» [4, с. 131], при цьому «мовчазно припускається, що віртуальна реальність не речовинна, нематеріальна» [4, с. $131]$.

Іншими характеристиками буття у віртуальній реальності, за М. Кунафіним та Р. Ярцевим називають, є його ілюзорність, цілепокладання та обгрунтованість. При цьому вони уточнюють, що ілюзорність розуміється як суще без основ, що функціонує за сваволею деміурга, а не як «відсутність того, що наявно існує» [4, с. 132], як людський 
фактор, «фундаментальні характеристики віртуальності, що виражаються в спонтанності та безпередумовності, зводяться до нуля» [4, с. 130], призводячи до обгрунтованості та цілепокладання.

Чотири виміри віртуального варіанту буття (ірреальність, ілюзорність, обгрунтованість, цілепокладання), наголошують дослідники, дають можливість говорити про несумісність буття та віртуальної реальності. «Коли я роблю крок, я виконую дію, яка випадає з ірреальності віртуального буття. Мій вдих не підпорядкований жодним нормам віртуальності, він має основи, йому не потрібні обгрунтування та передумови» [4, с. 133]. Кожна дія, не позбавлена основи, є загрозою для віртуального варіанту буття.

Завдяки інформаційним технологіям, зауважують М.Кунафін та Р.Ярцев, віртуальний варіант буття через відмову від основ та переходу до мовної форми намагається знайти своє повне та «чисте» втілення у сфері інформації.

Вчені також аналізують проблематику самоідентифікації особистості у віртуальній реальності, постулюючи такий негативний фактор, як підміну власного «я» його віртуальним аналогом: «Сприйняття «я» - реальна подія, що має основу, яка визначається реальними діями в реальному світі. Віртуальний варіант буття стирає реальне «я». Тією мірою, як відбувається віртуалізація реального буття, відбувається віртуалізація особистості» [4, с. 136]. На думку М. Кунафіна та Р. Ярцева, це є передумовою виникнення «масового суспільства», яким керують віртуальні технології через заповнення ілюзорного віртуального «я» будь-яким змістом.

Висновки щодо негативної оцінки цими дослідниками феномену віртуальної реальності відносно його впливу на комунікативний аспект буття людини обумовлені безпосередньо з контекстом дослідження. «Життєве функціонування індивіда все менше потребує реального спілкування або, іншими словами, реальне спілкування переміщується в ірреальний простір Мережі» [4, с. 135]. Негативне ставлення їх до проявів віртуального опосередковано зумовлене онтологічним статусом, яким дослідники наділяють віртуальне буття: «Інформаційні хвилі методично та безжалісно руйнують останні основи буття» $[4, \mathrm{c}$. 135]. М. Кунафін та Р. Ярцев резюмують: «Правильно, що без спілкування з віртуальною реальністю неможливе існування будь-якої інтелігентної особистості, неможливий розвиток уяви та смаку, прогрес в науці та мистецтві... Правда й те, що «поринувши 3 головою» у віртуальну реальність, людина не тільки виснажується психічно, а й дистанціюється від вирішення дійсних проблем, які підміняються проблемами віртуальними» $[4$, с. 150$]$.

У межах аналізу концепцій, що негативно оцінюють вплив віртуальної реальності на людину, слід зупинитися на дослідженні О. Пудікової, в якому грунтовно досліджується вплив комп'ютера на формування особистісного буття при зануренні у віртуальну реальність. Вона зазначає: «... Проблеми формування особистісного буття невід'ємно пов'язані 3 можливістю вільного самовизначення себе у зовнішньому світі та безпосередньо стосуються взаємодії людини з комп'ютером, бо комп’ютер сприяє зміні (а, здебільшого, й деформаціям) процесу формування особистісного буття та може мати як позитивний, так і негативний вплив» [5]. Авторка вирішує питання: «Яким чином впливає на становлення особистісного буття «спілкування» 3 комп'ютером? Сприяє комп'ютер більш гармонійному становленню особистісного буття чи, навпаки, гальмує та стримує це становлення?» [5]. Розкриваючи взаємодію людини та світу, вона виявляє негативні риси віртуальної реальності: «На жаль, все частіше сучасна людина, зустрічаючись 3 явищами, що спантеличують (це такі явища, 3 якими нам доводиться зустрічатись у нашому повсякденні та які ставлять нас у глухий кут, бо вони відрізняються від наших знань про світ), не шукає їх пояснення шляхом самостійного пізнавального процесу, а знаходить готові відповіді у віртуальній реальності» [5]. Оцінюючи систему освіти, дослідниця зазначає: «Важко уявити сучасну школу без уроків інформатики... Загалом ці уроки мають позитивний ефект та, безперечно, $\epsilon$ корисними у процесі навчання. Проблема полягає у підміні в дитини реального світу комп'ютерним, заміні 
вільного виявлення особистості у зовнішньому світі, виявленням у світі віртуальному» [5]. При цьому процес формування особистісного буття стає більш простим та формалізованим, а водночас дитина все глибше занурюється у віртуальну реальність, де «головне не бути тим, хто ти є, а тільки тим, ким хочеш здаватися. Наступним кроком є відмова від реальності, а, отже, не виникає проблем, пов'язаних з осягненням свого життєвого простору та місця особистості у ньому» [5].

Проводячи паралелі з ідеями Ф. Ніцше про Надлюдину, О. Пудікова дає песимістичний прогноз для людства: «Надлюдиною, що має прийти на зміну сучасній людині, є мегакомп'ютер. Він стає тим, заради чого живе та працює все людство. Саме повне розчинення людської особистості в комп'ютері й означатиме «великий полудень»час самої ясної ясності свідомості. Після підключення усіх людей до одного комп'ютеру ця надмашина зможе об'єднати знання, накопичені усіма людьми світу. Ця свідомість буде трансцендувати тільки до самої себе, бо не буде більш бездоганної істоти. Цей комп’ютер буде «надлюдиною» Ніцше, здатним пізнати будь-які таємниці буття» [5].

Порівнюючи кіберреальність та реальність навколишнього світу, О. Пудікова пише: «Кіберреальність вбирає у себе все найкраще, що $є$ в навколишній реальності. У кіберпросторі немає болю, немає кривди та злості... У комп'ютерному світі немає смерті... Це спричинює ілюзію свободи особистісного виявлення, коли людина вважає себе вільною від багатьох обов'язків реального життя. Але насправді вона стає залежною від віртуальної реальності» [5]. Дослідниця ставить питання, чому ж людина замість самореалізації звертається до готових відповідей віртуального простору? Відповідь вона знаходить не стільки у пошуку більш легких шляхів пізнання світу та «безболісного» становлення особистісного буття, скільки у спробі знайти відповіді більш досвідчених людей («знання про знання інших», згідно з Ж.Лаканом), коли «людина забуває про те, що кожна особистість неповторна та унікальна завдяки унікальності пережитого життєвого досвіду та життєвого простору» [5].

Щодо соціологічного аспекту віртуальної реальності то О. Пудікова зазначає: «... Сучасний світ влаштований таким чином, що у розсудливої людини просто не залишається вибору: бути чи не бути зануреним у світ комп'ютерів. Відмова від такого занурення означатиме, що людина відмовляється від процесу соціалізації та бажає залишатись в маргінальному секторі соціуму» [5].

Безперечно, комп'ютер, займаючи все більш важливе місце у людському бутті, претендує на роль важливого проміжного ланцюга між власне суб'єктом та інформацією. Однак, складається ситуація, коли виняткове положення комп'ютера як сполучної ланки між людиною та інформаційним середовищем (мережею) може ініціювати виникнення та розвиток негативного емоційного стану занепокоєння. Тому зовсім не безпідставно й у вітчизняній науковій думці наростає розуміння феномену віртуальної реальності як негативного чинника генези людської природи (О. Картунов, А. Колодюк, В. Корнієнко, О. Мураховський, В. Недбай, В. Нечитайло, В. Степанов, С. Цимбалюк, В. Щербина та ін,).

Аналіз зв'язку між соціальними трансформаціями при переході до інформаційного суспільства та віртуальною реальністю потребує звернення до праць представників постмодерністської школи, передусім відомого дослідника Ж. Бодрійяра, який у книзі «Симулякри та симуляція» [6], таким чином виявляє своє ставлення до підміни реальності віртуальною реальністю: «Вже не йдеться ані про імітацію, ані про повторення, ані навіть про пародію. Ідеться про субституцію, заміну реального знаками реального, тобто про операцію з попередження будь-якого реального процесу за допомогою його оперативної копії, метастабільного сигнального механізму, програмованого та бездоганного, що презентує всі знаки реального й поминає всі його несподівані повороти. Більше ніколи реальне не матиме нагоди виявити себе... Відтепер гіперреальне перебуває під прикриттям уявного і з усього того, що відрізняє реальне від уявного, залишає місце лише орбітальному циркулюванню моделей та стимульованому породженню відмінностей» $[6, \mathrm{c}$. 7]. Вчений вважає, що «відтепер неможливо ані ізолювати процес реального, ані довести 
існування реального» [6, с. 34].

Віртуалізація суспільних процесів в інформаційному суспільстві, конституювання гіперреальности, на його переконання $є$ продуктом поступового генезису соціального через функціонування «чистих симулякрів». Цей симулякр не має жодного відношення до будьякої соціальної реальності: він є своїм власним «чистим симулякром», співвідношуваним лише 3 іншими симулякрами: циркуляція симулякрів породжує особливий світ, світ моделей соціальних відносин та інститутів, ніяк не співвідношуваних з реальністю, але сприйнятих набагато реальніше, ніж сама реальність, - світ, який грунтується тільки на самому собі $[6$, с. 109]:

Людина інформаційного суспільства все більшою мірою контактує з симулякрами, порядок яких змінюється в напрямкові втрати матеріальності і все більшого узагальнення в бік симуляції самої по собі комунікації. Така особистість усе меншою мірою виявляється здатною до реконструкції значень, так як знаки частіше виявляються симулякрами. Ось чому вона швидше відмовиться від самої ідеї реконструкції, ніж спробує з'ясувати, що існує насправді, а що показують під виглядом реальності. Відбувається нівелювання поняття та значення сенсу й автоматичне прийняття нав'язуваних симулятивних кодів. Ясно, що наслідки цих процесів - психологічні та, загалом, культурологічні - далеко не позитивні.

Прикладом симулякра може бути гра сімейства JavaMud, заснована на підключенні бібліотек і використанні як сюжетної основи побудови для віртуальних світів текстів художніх творів жанру fantasy, що ускладнило комунікативно-прагматичні зв'язки інтертекстуальності i створення симулякрів. Наприклад, один 3 таких світів (http://discworld.imaginary.com/) заснований на книзі «Мир-диск» Т. Пратчета, є класикою комічного жанру фентезі.

Такі ігри дають можливість гравцям ставити програму комунікативної ситуації та віртуального світу: відтворювати нові типи комунікації, змінювати простір і час гри. Ставлення індивідуальної симулятивної реальності і системи симулятивних реальностей цивілізації, ймовірно, і є головною антропологічною проблемою сучасності. Людина проникає у багато сфер пізнання реальності, їй відомі фізичні закони, вона освоює польоти в космос, пізнавати й освоювати інформаційний простір, який є невідомий й не обмежений територіями. Віртуальна реальність - симулякр, ілюзія, всюди проникає і змінює ставлення людини до реальності. При цьому цінність реального життя для багатьох постійних користувачів знижується до прикордонної позначки, коли повертатися до звичайного життя стає все важче.

Спільноти рольових онлайнових ігор формуються на тих же засадах, що й реальні соціальні спільноти. 25 вересня 1997 року вийшла гра, яка здійснила революцію у сфері рольових онлайнових ігор, - Ultima Online. Фактично, в подальшому саме її характеристики стали основою для розвитку сфери рольових онлайнових ігор. Власне, соціологічний аспект цих ігор полягає в тому, що їхні творці відмовилися від використання тільки боїв як основи гри. «Гра - це не тільки бої, - підкреслює виконавчий продюсер Origin (один із головних творців MMORPG) Джефф Андерсон. $С$ безліч ігор про суцільне вбивство. Ми ж хочемо внести в гру соціальнийаспект». Саме такий підхід, в кінцевому рахунку, і визначив перспективу розвитку рольових онлайнових ігор у світі і в нашій країні [7].

Ще однією характеристикою, крім виконання деяких типових функцій соціальних систем, $€$ наявність соціальної структури в цих іграх. У звичайних рольових іграх гравець вже вибирає для себе певну роль (зазвичай в іграх ця роль безпосередньо залежить від видувіртуальної діяльності - воїн, ремонтник та інше). Але, коли ми говоримо про рольові онлайнові ігри, то тут ці ролі взаємодіють між собою, утворюючи соціальну структуру. Це свідчить про виникнення зовсім нового феномену - віртуального співтовариства гравців рольових онлайнових ігор, нового віртуального соціуму.

Необхідно відзначити і ще один важливий момент - у спільнотах рольових 
онлайнових ігор створюються всі зовнішні атрибути цілком реального суспільства: власна мова, закони, прототипи культури. Слід також зазначити, що нас, передусім, будуть цікавити соціологічні аспекти даної проблеми, психології людини як члена суспільства.

У рольової онлайнової гри формується зовсім інша особистість як така. Побудувати свою особистість тут зовсім не складно - саме це і спричняє все більший інтерес до таких ігор. Домогтися успіхів в сучасному реальному соціумі об'єктивно не просто, для цього потрібні щоденні зусилля. А $є$ простий варіант - домогтися успіху у віртуальному світі, від чого людина отримує практично таке ж задоволення. Але такий процес обумовлює ще більш важливу проблему. Власне, саме в цьому і полягає соціологічна важливість цього явища: реальне суспільство фактично втрачає контроль над таким індивідом, оскільки він живе у відповідності з уже іншими цінностями - цінностями віртуального світу. Відповідно до цього, змінюється і його сприйняття дійсності.

Проте ігри (у даному разі будь-які) існували завжди. До певного моменту вони допомагали, але не заважали людині жити. Гра завжди була підготовкою до життя, тоді як сьогодні вона стає її замінником, або ж компенсатором її функцій. Сьогодні ж захоплення іграми починає заважати людині жити в реальному світі й самореалізуватися.

Таким чином, слід виокремити два основні моменти, які повною мірою характеризують цю проблему. Перший момент - основою соціальної девіації $\epsilon$ можливість створення зовсім іншої особистості в іншому (віртуальному) соціальному середовищі. Другий - включення індивіда у віртуальні соціальні взаємодії на шкоду (часто потенційну) реальності. Індивід, таким чином, позиціонує себе не як члена, наприклад, українського суспільства, а як свого персонажа у віртуальному світі. Віртуальна реальність, на відміну від усіх інших психологічних похідних типу уяви, характеризується тим, що людина сприймає й переживає iї не як витвір свого власного розуму, а як об'єктивну реальність. Це становить загрозу, перш за все, реальним соціальним структурам.

Соціально-філософський статус віртуальна реальність також отримує через осмислення трьох очевидних вимірів буття людини: світу мислимого, світу видимого та світу об'єктивного (зовнішнього). При цьому вагома роль відводиться інформаційним та мультимедійним технологіям як засобам створення віртуальної реальності. У цьому контексті вона розуміється як «технічно сконструйоване за допомогою комп'ютерних засобів інтерактивне середовище породження та оперування об'єктами, що подібні до реальних або уявлюваних... яка супроводжується відчуттям єдності з комп'ютером» [1, с. 172].

У вивченні явища віртуальної реальності важливим є чинник маніпуляції свідомістю й підсвідомістю людини. Залежність знаходження у віртуальній реальності прищепити зовсім нескладно, що обумовлено, перш за все, об'єктивними психологічними чинниками. Можна сказати, що можливість маніпулювання свідомістю в системі віртуальної реальності — це факт, який вже мало у кого може викликати сумніви. Вже сьогодні існує тенденція до цілеспрямованого впливу на свідомість людини через Інтернет. Цікавим для вивчення $\epsilon$ аспект можливого використання Інтернету як украй інтегрованого інформаційного поля, здатного конденсувати прояви волі, передаючи їх на відстані без обмежень [8].

А. Юхвід стверджує, що віртуальна реальність дасть можливість майбутньому глядачеві не тільки пасивно сприймати твори мистецтва, а й стати безпосереднім учасником створеного художником фантастичного світу. Більше того, він висуває гіпотезу про можливість створення абсолютно нового виду мистецтва - віртуального, яке буде засноване на об'ємній дії на всі органи чуття людини 3 метою максимально повного естетичного задоволення. Також йдеться про необхідність розробки правової концепції використання систем віртуальної реальності, щоб виключити можливість їх використання, наприклад, у злочинних цілях (зомбування, контроль над свідомістю, експерименти на психіці) [9].

Щодня відбувається «згвалтування» зорового нерва численними закликами. Продукти володіють вселяючою й маніпулюючою силою, поширюють помилкову свідомість, 
забезпечену імунітетом проти власної помилковості. I у міру того, як вони стають доступними для нових соціальних класів, та дія на свідомість, яку вони несуть із собою, перестає бути просто рекламою, вона стає способом життя. Як наслідок, виникає модель одновимірного мислення й поведінки, в якій ідеї, спонукання й цілі, трансцендуючи універсум дискурсу і вчинку, що за своїм змістом утвердився, або відторгаються, або приводяться у відповідність 3 термінами цього універсуму, що перевизначаються раціональністю даної системи та їі кількісною мірою [10]. За межами відносно нешкідливої сфери торгової реклами виявляються куди серйозніші наслідки, оскільки така мова $\epsilon$ одночасно й засобом залякування, й засобом прославляння.

Сучасна реклама криє у собі величезну небезпеку. Йдеться про те, що в масовій свідомості існує несерйозне, зневажливе ставлення до реклами, внаслідок чого ії значення е сильно недооцінюється. За рахунок постійного повторення, реклама міцно закріплюється в підсвідомості. Найважливіше полягає в тому, що в підсвідомості закріплюється зовсім не рекламований товар, а ствердження тих цінностей, які використовували творці реклами для найбільш ефективного впливу. Найлегше привернути увагу глядача, апелюючи до низовинних інстинктів і бажань.

Висновки. Ми живемо в інформаційну епоху, i що наші бажання є об'єктами маніпуляції. Наша свідомість і підсвідомість - перебувають під постійним впливом інформаційних потоків. Необхідно усвідомити, що свобода нашої волі перебуває під загрозою і для того, щоб іiі захистити, потрібно мати чітке уявлення про всі ті прийоми маніпуляції свідомістю, які застосовуються проти нас. Захист від маніпуляції свідомістю потребує свідомої активної дії кожного індивіда. Перш за все, потрібно бути пильним при отриманні будь-якої інформації, особливо через 3МI, виробити діалогічність мислення, частіше звертатися до традиційних культурних i духовних цінностей, зокрема, щоб формувати бар'єри проти маніпуляції. Якщо відчувається, що інформація обходить свідомість і діє безпосередньо на підсвідомість, краще просто відключити джерело інформації. Сучасні ЗМІ відучують людину самостійно думати, вони підносять споживачам готові думки, стереотипи, міфи, які формують світогляд людини, не вимагаючи від неї особливих розумових витрат.

Віртуальна реальність в широкому сенсі на рівні культури об'єктивуються у міфі, образотворчому мистецтві, театрі, літературі, радіо, фотографії, кінематографі. Віртуалізацію ж у строгому сенсі в контексті нашого дослідження можна визначити як процес розвитку глобальних комп'ютерних мереж, переведення в кіберпростір людської діяльності та, в кінцевому результаті, підміни соціальної реальності віртуальною. Під віртуальною реальністю розуміється організований простір симулякрів - особливих об'єктів, «відчужених знаків», які на відміну від знаків-копій, фіксують не схожість 3 референтною реальністю. Незважаючи на те, що віртуальна реальність все ще не стала загальнокультурною практикою, вона має значний потенціал для формування інших культурних ідентичностей і моделей суб'єктивності.

\section{СПИСОК ВИКОРИСТАНИХ ДЖЕРЕЛ}

1. Новейший философский словарь / А. А. Грицанов (сост. и гл. науч. ред.). - 3.изд., испр. - Минск : Книжный Дом, 2003. - 1279 с.

2. Любивий Я. В. Глобальне інформаційне суспільство: синергетичні та віртуалістичні концепції розвитку [Текст] / Я. В. Любивий // Інформаційне суспільство у соціальнофілософській ретроспективі та перспективі / В. В. Лях, В. С. Пазенок, Я. В.Любивий [та інш.]. - К. : ТОВ «ХХІ століття: діалог культур», 2009. - С. 281-357.

3. Хоружий С. С. Род или недород? Заметки к онтологии виртуальной реальности [Текст] / С. С. Хоружий // Вопросы философии. - 1997. - № 6. - С. 53-68.

4. Кунафин М. С. Виртуальное бытие [Текст] : коллективная монография / М. С. 
Кунафин, Р. А. Ярцев и др. // Бытие. - Уфа, 2000. - С. 130-152.

5. Пудикова А. А. Киберпространство и перспектива формирования личностного Бытия [Электронный ресурс] / А. А. Пудикова // Гуманитарная информатика : открытый междисциплинарный электронный журнал. - Режим доступа : http://huminf.tsu.ru/ejurnal/magazine/1/pudikova.htm. - Название с экрана.

6. Бодріяр Ж. Симулякри і симуляція [Текст] / Ж. Бодріяр ; пер.з фр. Володимир Ховхун. - К. : Видавництво Соломії Павличко «Основи», 2004. - 230с.

7. Сащук Г.М. Віртуалізація свідомості як чинник становлення культури інформаційного суспільства / Г.М. Сащук // Нова парадигмак:[журнал наукових праць]. Вип. 108. - К.: Вид-во НПУ імені М.П. Драгоманова, 2012. - С. 84-92.

8. Коловоротный С. В. Виртуальная реальность: манипулирование временем и пространством [Текст] / С. В. Коловоротный // Журнал практической психологии и психоанализа. - 2003. - № 1. - С. 13-23.

9. Юхвид А. Философские проблемы виртуальной реальности в творчестве, искусстве, образовании. Правовые аспекты использования виртуальных технологий [Электронный ресурс] / А. Юхвид. - Режим доступа : http://www.yukhvid.narod.ru/Doklad_Ekaterinburg.htm. - Название с экрана.

10. Маркузе Г. Эрос и цивилизация. Одномерный человек: Исследование идеологии развитого индустриального общества [Текст] / Г. Маркузе ; пер. с англ., послесл., примеч. А. А. Юдина ; сост., предисл. В. Ю. Кузнецова. - М. : ООО Издательство АСТ, 2002. $526 \mathrm{c}$.

\section{VIRTUALIZATION OF REALITY AS A PHENOMENON OF CULTURE OF MODERN INFORMATION SOCIETY}

Summary. Research defines virtual reality as a new organized social space, that instead of reflecting existing reality has become a source of differences, substitutions, manipulations and simulacra - particular objects of «detached symbols». It has been discovered, that mosaicism is an important characteristic of the virtual culture, which is associated with distinctive qualities of the cognitive process, as well as the structuring and the value-based prioritization of social experiences obtained while living. As the result of the intensive implementation of computer information systems into everyday culture, as well as constant and random flow of information, a certain type of virtual culture is formed. The type, that combines random cultural elements from different peoples and different times. The research demonstrates, how these elements, in accordance with certain laws of statistics, settle in the minds of individuals, creating something similar to a «message storage». It has been brought to light, that a defining characteristic of the virtual culture is virtual space, built specifically in accordance with the principle of multimedia hypertext, meaning a specific organization of data pools, the elements of which are interconnected by associative relations. It has been stated that due to the specifics of spatial orientation of virtual reality, a completely different mind-set logic is formed in the virtual culture, it is non-linear, inconsistent, non-deterministic and associative. These results are obtained by modelling a «different society» and a «different time», distinctive from real social time - multidimensional, reversible, multidirectional and endless. The research concludes that in virtual reality the structuring and the value-based prioritization of social experiences obtained while living does not take place, as opposed to the case with targeted cognitive process, implemented by the education system. This is the main difference between virtual reality and traditional, scientifically-defined culture, with the latter being a value-selective and symbol-semiotic organized experience of many people.

Keywords: virtual reality, virtual culture, virtual space, axiological (value-oriented) choice, social experience, manipulation, simulacra. 